\title{
From microRNA functions to microRNA therapeutics: Novel targets and novel drugs in breast cancer research and treatment (Review)
}

\author{
ROBERTA PIVA $^{1}$, DEMETRIOS A. SPANDIDOS ${ }^{2}$ and ROBERTO GAMBARI ${ }^{3}$ \\ ${ }^{1}$ Department of Biomedical and Specialty Surgical Sciences, Ferrara University, Ferrara, Italy; \\ ${ }^{2}$ Department of Clinical Virology, University of Crete School of Medicine, Heraklion, Crete, Greece; \\ ${ }^{3}$ Department of Life Sciences and Biotechnology, Ferrara University, Ferrara, Italy
}

Received July 24, 2013; Accepted August 12, 2013

DOI: 10.3892/ijo.2013.2059

\begin{abstract}
MicroRNAs (miRNAs or miRs) are a family of small non-coding RNAs that regulate gene expression by the sequence-selective targeting of mRNAs, leading to translational repression or mRNA degradation, depending on the degree of complementarity with target mRNA sequences. miRNAs play a crucial role in cancer. In the case of breast tumors, several studies have demonstrated a correlation between: i) the expression profile of oncogenic miRNAs (oncomiRs) or tumor suppressor miRNAs and ii) the tumorigenic potential of triple-negative [estrogen receptor (ER), progesterone receptor (PR) and Her2/ neu] primary breast cancers. Among the miRNAs involved in breast cancer, miR-221 plays a crucial role for the following reasons: i) miR-221 is significantly overexpressed in triplenegative primary breast cancers; ii) the oncosuppressor $\mathrm{p} 27^{\mathrm{Kip} 1}$, a validated miR-221 target, is downregulated in aggressive cancer cell lines; and iii) the upregulation of a key transcription factor, Slug, appears to be crucial, since it binds to the miR-221/ miR-222 promoter and is responsible for the high expression of the miR-221/miR-222 cluster in breast cancer cells. A Slug/ miR-221 network has been suggested, linking miR-221 activity with the downregulation of a Slug repressor, leading to Slug/ miR-221 upregulation and $\mathrm{p} 27^{\mathrm{Kip1}}$ downregulation. Interference with this process can be achieved using antisense miRNA (antagomiR) molecules targeting miR-221, inducing the downregulation of Slug and the upregulation of $\mathrm{p} 27^{\mathrm{Kip} 1}$.
\end{abstract}

Correspondence to: Professor Roberto Gambari, Department of Life Sciences and Biotechnology, Ferrara University, Via Fossato di Mortara 74, I-44123 Ferrara, Italy

E-mail: gam@unife.it

Abbreviations: miRNA, microRNA; ER, estrogen receptor; PNA, peptide nucleic acid; 3'UTR, 3' untranslated region

Key words: microRNAs, breast cancer, miR-221, Slug, p27 ${ }^{\mathrm{Kip} 1}$, peptide nucleic acid, microRNA replacement therapy, antagomiR

\section{Contents}

1. Introduction

2. MicroRNAs and cancer

3. OncomiRs and MetastamiRs

4. Oncosuppressor microRNAs

5. MicroRNAs in breast tumors

6. Plasma miR-221 as a diagnostic marker in breast cancer

7. Connecting miRNA-221 with the expression of cellular genes altered in breast cancer cells: the Slug/miR-221 network

8. Effects of antagomiRs targeting oncomiRs

9. Novel drugs in miRNA therapeutics: peptide nucleic acid (PNA)

10. Conclusion

\section{Introduction}

MicroRNAs (miRNAs or miRs) (Fig. 1) are a family of small (19 to 25 nucleotides in length) non-coding RNAs that regulate gene expression by the sequence-selective targeting of mRNAs, leading to translational repression or mRNA degradation, depending on the degree of complementarity with target mRNA sequences (1-5). Since their discovery and first characterization, the number of miRNA sequences deposited in the miRBase databases is increasing (6-10). Considering that a single miRNA can target several mRNAs and a single mRNA may contain several signals for miRNA recognition in the 3'UTR sequence, it has been calculated that at least $10-40 \%$ of human mRNAs are a target for miRNAs (11-13). Hence, the identification of validated targets of miRNAs is of great importance.

This specific field of miRNA research has confirmed that the complex networks constituted by miRNAs and mRNA targets coding for structural and regulatory proteins lead to the control of highly regulated biological functions, such as differentiation, cell cycle and apoptosis (14-16). The low expression of a given miRNA is expected to be linked with a potential expression of target mRNAs. Conversely, the high expression of miRNAs is expected to negatively affect the biological functions of target mRNAs (1-5). 


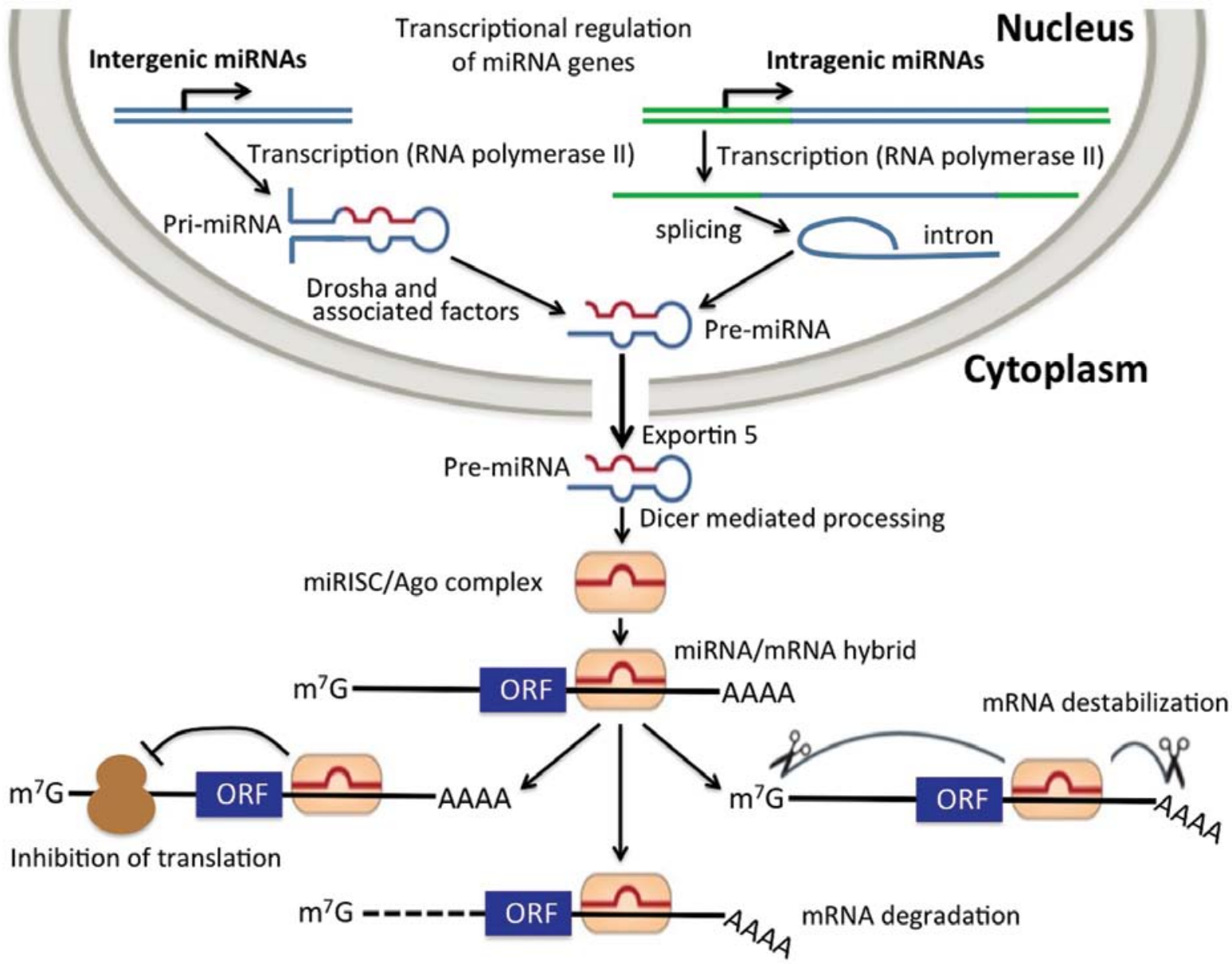

Figure 1. Biogenesis of microRNAs.

Alterations in miRNA expression have been demonstrated to be associated with a variety of human pathologies, and the guided alterations of specific miRNAs have been suggested as novel approaches for the development of innovative therapeutic protocols. miRNA therapeutics is a novel field in which miRNA activity is the major target of intervention (17-21). The inhibition of miRNA activity can be readily achieved by the use of small miRNA inhibitors, oligomers, including RNA, DNA and DNA analogues (miRNA antisense therapy) $(19,22-28)$. On the contrary, an increase in miRNA function (miRNA replacement therapy) can be achieved by the use of modified miRNA mimetics, such as plasmid or lentiviral vectors carrying miRNA sequences $(20,21,29-37)$.

\section{MicroRNAs and cancer}

miRNAs play a pivotal role in all the stages of cancer. The literature on this specific issue is impressive (22-37). As a first example, miR-372 and miR-373 were identified as oncogenes, after a screening of hundreds of miRNAs in testicular germ cell tumors (38). The mechanisms of action of these miRNAs involve the negative regulation of the expression of the LAST2 tumor suppressor gene, blocking the pathway of one of the key tumor suppressors, p53 (39). Accordingly, using breast cancer MCF-7 cells as a model system, Huang et al demonstrated that miR-373 promotes tumor invasion and metastasis (40).
A similar tumor-promoting activity has been exhibited by miR-221 and miR-222, which can stimulate the proliferation of human prostate carcinoma cell lines following the inhibition of the expression of the tumor suppressor p27 ${ }^{\text {Kipl }}$ (41).

An opposite effect on tumor development has been displayed by other miRNAs; for instance miR-31 expression levels inversely correlate with the metastatic ability of breast tumor cell lines and the inhibition of miR-31 promotes metastasis. Another study revealed that miR-31 blocks several steps of metastasis, including local invasion, extravasation or initial survival at a distant site, and metastatic colonization (42). Taken together, these data demonstrate that miRNAs play a double role in cancer, behaving both as oncogenes or tumor suppressor genes.

\section{OncomiRs and metastamiRs}

In general, a miRNA able to promote cancer targets mRNAs encoding tumor suppressor proteins, while miRNAs exhibiting tumor suppressor properties usually target mRNAs encoding oncoproteins. miRNAs which have been demonstrated to play a crucial role in the initiation and progression of human cancer are defined as oncogenic miRNAs (oncomiRs) (22-28). Moreover, miRNAs have been firmly demonstrated to be involved in cancer metastasis (metastamiRs) (43-46). Thus, therapeutic strategies involving miRNA silencing have been 
Table I. Examples of oncomiRs suitable for antagomiR-based miRNA targeted therapy of cancer.

\begin{tabular}{|c|c|c|c|c|}
\hline Cells/tissues & miRNA target & $\begin{array}{l}\text { Modulated } \\
\text { mRNA }\end{array}$ & $\begin{array}{l}\text { Effects following } \\
\text { antagomiR treatement }\end{array}$ & Authors/(Refs.) \\
\hline $\begin{array}{l}\text { Human } \\
\text { glioblastoma }\end{array}$ & $\operatorname{miR}-27 \mathrm{a}$ & FOXO3a & $\begin{array}{l}\text { Suppression of U87 growth } \\
\text { in vitro and in vivo }\end{array}$ & Ge et al (22) \\
\hline $\begin{array}{l}\text { Cutaneous } \\
\text { squamous } \\
\text { cell carcinoma } \\
\text { (SCC) }\end{array}$ & miR-155 & $\mathrm{CDC73}$ & $\begin{array}{l}\text { Decreased cell viability, } \\
\text { increased apoptosis and } \\
\text { marked regression of } \\
\text { xenografts in nude mice }\end{array}$ & Rather et al (23) \\
\hline $\begin{array}{l}\text { Malignant } \\
\text { astrocytoma } \\
\text { cells }\end{array}$ & miR-335 & Daam1 & $\begin{array}{l}\text { Growth arrest, cell apoptosis, } \\
\text { invasion repression and marked } \\
\text { regression of astrocytoma xenografts }\end{array}$ & Shu et al (24) \\
\hline Neuroblastoma & miR-92 & DKK3 & $\begin{array}{l}\text { Increased release of the tumor } \\
\text { suppressor Dickkopf-3 (DKK3), } \\
\text { a secreted protein of the DKK } \\
\text { family of Wnt regulators }\end{array}$ & Haug et al (25) \\
\hline Glioma & miR-381 & LRRC4 & $\begin{array}{l}\text { Decreased cell proliferation } \\
\text { and tumor growth }\end{array}$ & Tang et al (26) \\
\hline Breast cancer & $\operatorname{miR}-10 b$ & Hoxd10 & $\begin{array}{l}\text { Suppression of formation } \\
\text { of lung metastases }\end{array}$ & Ma et al (27) \\
\hline Prostate cancer & $\mathrm{miR}-221 / \mathrm{miR}-222$ & $\mathrm{p} 27$ & Reduction of tumor growth & Mercatelli et al (28) \\
\hline
\end{tabular}

suggested, based on the roles of these small non-coding RNAs as oncogenes (22-28).

Another very interesting feature of miRNAs has been found by studying cancer-associated miRNAs in different experimental model systems; cancer-specific miRNAs are present in extracellular body fluids and may play a crucial role in the cross-talk between cancer cells and surrounding normal cells (47-52). Of note, evidence of the presence of miRNAs in serum, plasma and saliva supports their potential as an additional set of biomarkers for cancer. Extracellular miRNAs are protected by exosome-like structures, small intraluminal vesicles shed from a variety of cells (including cancer cells), with a biogenesis connected with the endosomal sorting complex required for transport machinery in multivesicular bodies. These extracellular structures, originally considered as a 'garbage bag' devoted to discarding degraded proteins, are now considered to play an important role as an intercellular communication tool. It is still unclear as to whether these exosome-associated miRNAs occur as a result of tumor cell death and lyses, or are actively excreted from tumor cells into the microenvironment. However, this novel secretory machinery of miRNAs may be involved in tumor-associated features, such as the enhancement of angiogenesis, the increase of cytokine secretion and migration to pre-metastatic niche. Table I illustrates a summarized list of oncomiRs and metastamiRs.

\section{Oncosuppressor microRNAs}

In addition to oncogenic activities, miRNAs exhibit, as has already been pointed out, oncosuppressor properties by targeting mRNAs encoding oncoproteins (29-37). Piovan et al recently explored the interaction between certain miRNAs and transcriptional factors involved in determining cell fate, including the well known 'genome guardian', p53 (53). They demonstrated that miR-205, an oncosuppressive miRNA lost in breast cancer, is directly transactivated by the oncosuppressor p53. Moreover, evaluating miR-205 expression in a panel of cell lines belonging to the highly aggressive triplenegative [estrogen receptor (ER), progesterone receptor (PR) and Her2/neu] breast cancer subtype, which still lacks an effective targeted therapy and is characterized by an extremely undifferentiated mesenchymal phenotype, the authors demonstrated that this miRNA is critically downregulated compared with a normal cell line. The re-expression of miR-205 strongly reduced cell proliferation, cell cycle progression and clonogenic potential in vitro, and inhibited tumor growth in vivo. The tumor suppressor activity of miR-205 is partially exerted by targeting of E2F1, one of the master regulators of cell cycle progression, and LAMC1, a component of the extracellular matrix involved in cell adhesion, proliferation and migration. In another study, Lee et al (54), demonstrated that an estrogen-downregulated miRNA, miR-34b, acts as an oncosuppressor that targets cyclin D1 and Jagged-1 (JAG1) in an ER $\alpha$-positive/wild-type p53 breast cancer cell line (MCF-7), as well as in ovarian and endometrial cells, but not in ER $\alpha$-negative or mutant p53 breast cancer cell lines (T47D, MBA-MB-361 and MDA-MB-435). The negative association between $\mathrm{ER} \alpha$ and miR-34b expression levels has also been found in $E R \alpha$-positive breast cancer patients. In addition, the overexpression of miR-34b has been shown to inhibit ER $\alpha$-positive breast tumor growth in an orthotopic mammary fat pad xenograft mouse model. Table II illustrates a summarized list of oncosuppressor miRNAs (29-37,55-58). 
Table II. miRNAs acting as tumor suppressor genes and are suitable for replacement therapy of cancer: selected examples.

\begin{tabular}{|c|c|c|c|c|}
\hline Tumor type & miRNA & Modulated mRNA & $\begin{array}{l}\text { Effects following pre-miRNA } \\
\text { administration }\end{array}$ & Authors/(Refs.) \\
\hline Acute leukemia & $\operatorname{miR}-27 a$ & Bax and Bad & $\begin{array}{l}\text { Inhibition of cell growth due, } \\
\text { at least in part, to increased } \\
\text { cellular apoptosis }\end{array}$ & Scheibner et al (29) \\
\hline $\begin{array}{l}\text { Oral squamous cell } \\
\text { carcinoma (OSCC) }\end{array}$ & miR-596 & LGALS3BP & Growth inhibition & Endo et al (30) \\
\hline Breast cancer & $\operatorname{miR}-302$ & AKT1 and RAD52 & $\begin{array}{l}\text { Sensitized radioresistant } \\
\text { breast cancer cells to } \\
\text { ionizing radiation }\end{array}$ & Liang et al (31) \\
\hline $\begin{array}{l}\text { Chronic myelogenous } \\
\text { leukemia (CML) cells }\end{array}$ & $\operatorname{miR}-33 a$ & Pim-1 & Decelerated cell proliferation & Thomas et al (32) \\
\hline Colon carcinoma & miR-33a & Pim-1 & Reduced tumor proliferation & Ibrahim et al (33) \\
\hline Colon carcinoma & $\operatorname{miR}-145$ & c-Myc and ERK5 & $\begin{array}{l}\text { Reduced tumor proliferation } \\
\text { and increased apoptosis }\end{array}$ & Ibrahim et al (33) \\
\hline Lung cancer & $\operatorname{miR}-34 a$ & $\begin{array}{l}\text { Repression of c-Met, Bcl-2; } \\
\text { partial repression of CDK } 4\end{array}$ & Block of tumor growth & Wiggins et al (34) \\
\hline Lung cancer & miR-let7 & $\begin{array}{l}\text { Negative regulation of the } \\
\text { cell cycle oncogenes RAS, } \\
\text { MYC and HMGA2 }\end{array}$ & Reduction of tumor growth & Trang et al (35) \\
\hline $\begin{array}{l}\text { Non-small cell lung } \\
\text { adenocarcinomas, } \\
\text { A549 cells }\end{array}$ & $\operatorname{miR}-29 b$ & CDK6, DNMT3B, MCL-1 & Inhibition of tumorigenicity in vivo & Wu et al (36) \\
\hline $\begin{array}{l}\text { Acute myeloid } \\
\text { leukemia (AML) }\end{array}$ & $\operatorname{miR}-29 b$ & $\begin{array}{l}\text { Downregulation of DNMTs, } \\
\text { CDK6, SP1, KIT and FLT3 }\end{array}$ & $\begin{array}{l}\text { Decreased AML cell growth and } \\
\text { impairement of colony formation; } \\
\text { longer survival of treated mice; } \\
\text { improvement of anti-leukemic } \\
\text { activity of decitabine }\end{array}$ & Huang et al (37) \\
\hline
\end{tabular}

\section{MicroRNAs in breast tumors}

As already presented in the previous chapters, miRNAs play a crucial role in breast tumors (59-73). Several studies have been undertaken with the objective of determining the correlation between the expression profile of oncomiRs and tumor suppressor miRNAs, and, in particular, the tumorigenic potential of triple-negative primary breast cancers. In the study by Radojicic et al (68) 49 primary triple-negative breast cancer cases, along with 34 matched tumor-associated normal samples were investigated for the expression of 9 miRNAs using qRT-PCR. Correlations between the expression of miR-10b, miR-21, miR-122a, miR-145, miR-205, miR-210, miR-221, miR-222 and miR-296 and the pathological features of the tumors were examined, as well as the effects of miRNA expression on patient overall and cancer-specific survival. miR-21, miR-210 and miR-221 were significantly overexpressed, whereas miR-10b, miR-145, miR-205 and miR-122a were significantly underexpressed in the triple-negative primary breast cancers. Significant correlations among all the studied miRNAs were scored both in the breast cancer and control tissues. The expression of miR-222 and miR-296 did not exhibit any significant difference between the breast cancer and normal tissue.
A number of studies $(61-67,74)$ have identified miR-221 and miR-222, as basal-like subtype-specific miRNAs that decrease the expression of epithelial-specific genes and increase the expression of mesenchymal-specific genes. In addition, the expression of these miRNAs increases cell migration and invasion; collectively, these are characteristics of epithelial-tomesenchymal transition (EMT). The basal-like transcription factor, FOSL1 (also known as Fra-1), directly stimulates the transcription of miR-221/222, and the abundance of these miRNAs decreases with the inhibition of MEK (mitogenactivated or extracellular signal-regulated protein kinase), placing miR-221/222 downstream of the RAS pathway. The miR-221/222-mediated reduction in E-cadherin abundance is dependent on their targeting of the 3'UTR of trichorhinophalangeal syndrome type 1 (TRPS1), which is a member of the GATA family of transcriptional repressors. TRPS1 inhibits EMT by directly repressing the expression of Zinc finger E-box-binding homeobox 2 (ZEB2). Therefore, these molecular data support the hypothesis that miR-221/222 contribute to the aggressive clinical behavior of basal-like breast cancer.

Furthermore, the expression of miR-221 is clearly involved in chemoresistence. Studies have revealed an elevated expression of miR-221 in adriamycin-resistant MCF-7/ADR cells. In conclusion, several studies have indicated that miR-221 is one of 


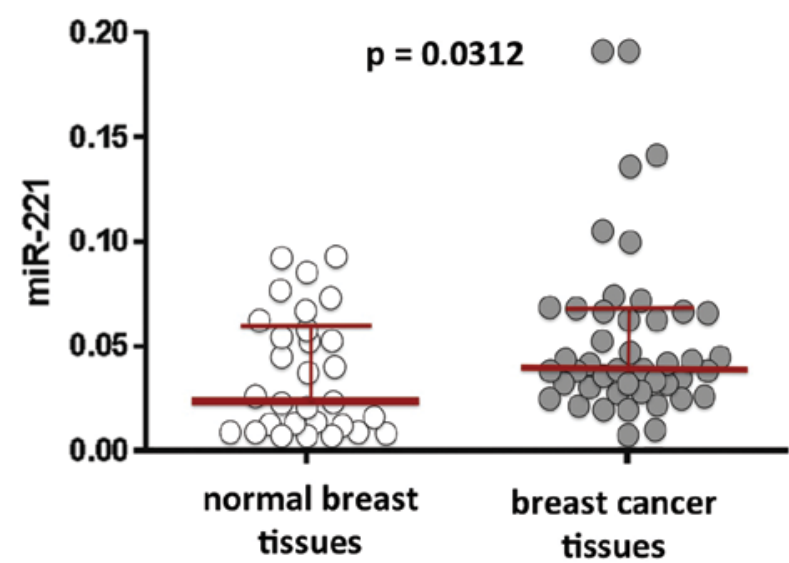

Figure 2. Distribution of the normalized expression levels of miR-221 in breast cancers and adjacent normal tissues. Bars indicate median values with interquartile range. Modified from the study by Radojicic et al (68).

the major miRNAs involved in breast cancer (75). Representative results concerning miR-221 in breast cancer tissues are illustrated in Fig. 2.

\section{Plasma miR-221 as a diagnostic marker in breast cancer}

In consideration of the importance of miR-221 in the tumor phenotype of breast cancer, several studies have been performed with the objective of analyzing miR-221 in biological fluids as a marker of breast cancer. Zhao et al (75) demonstrated that plasma miR-221 can be considered as a predictive biomarker for chemoresistance in breast cancer patients who have previously received neoadjuvant chemotherapy. The expression levels of circulating miR-221 were assessed in the plasma of 93 breast cancer patients who had previously received neoadjuvant chemotherapy (NAC), as well as in 32 healthy individuals. The correlation between miR-221 and clinicopathological features and chemosensitivity was also analyzed. The expression level of miR-221 was significantly associated with the hormone receptor (HR) status. Patients with higher plasma miR-221 levels tended to be HR-negative. Patients with varying miR-221 levels had significant differences in the overall response rate but not in the pathological complete response rate. These results indicate that plasma miR-221 may be a predictive biomarker for sensitivity to NAC in breast cancer patients.

7. Connecting miRNA-221 with the expression of cellular genes altered in breast cancer cells: the Slug/miR-221 network

This issue has great impact on the design of novel therapeutic approaches. On the one hand, it is very important to determine whether the expression of the miR-221/miR-222 cluster is under the transcriptional regulation of cellular proteins (for instance tumor-associated transcription factors). On the other hand, it is imperative to determine which mRNAs are specifically targeted by miR-221 (for instance tumor-suppressor mRNAs) determining the tumorigenic potential of this miRNA. Finally, it should be verified whether mRNAs regulated by miR-221 encode proteins able to regulate upstream miR-221 modifiers, therefore activating a 'vicious intracellular cycle'. As regards these issues, a number of studies have been published. Lambertini et al (74) recently demonstrated that the Slug transcription factor binds to the miR-221/miR-222 promoter and is responsible for the high expression of the $\mathrm{miR}-221 / \mathrm{miR}-222$ cluster in breast cancer cells. In order to investigate the possible correlation between the Slug transcription factor and miR-221, they performed Slug gene silencing in MDA-MB-231 breast cancer cells and evaluated the expression of genes involved in supporting the breast cancer phenotype by qRT-PCR and western blot analysis. Chromatin immunoprecipitation and wound healing assays were employed to determine a functional link between these two molecules. The results of their study (Fig. 3) revealed that Slug silencing significantly decreased the level of miR-221 and vimentin, reactivated ER $\alpha$ and increased E-cadherin and TRPS1 expression (74). It was demonstrated
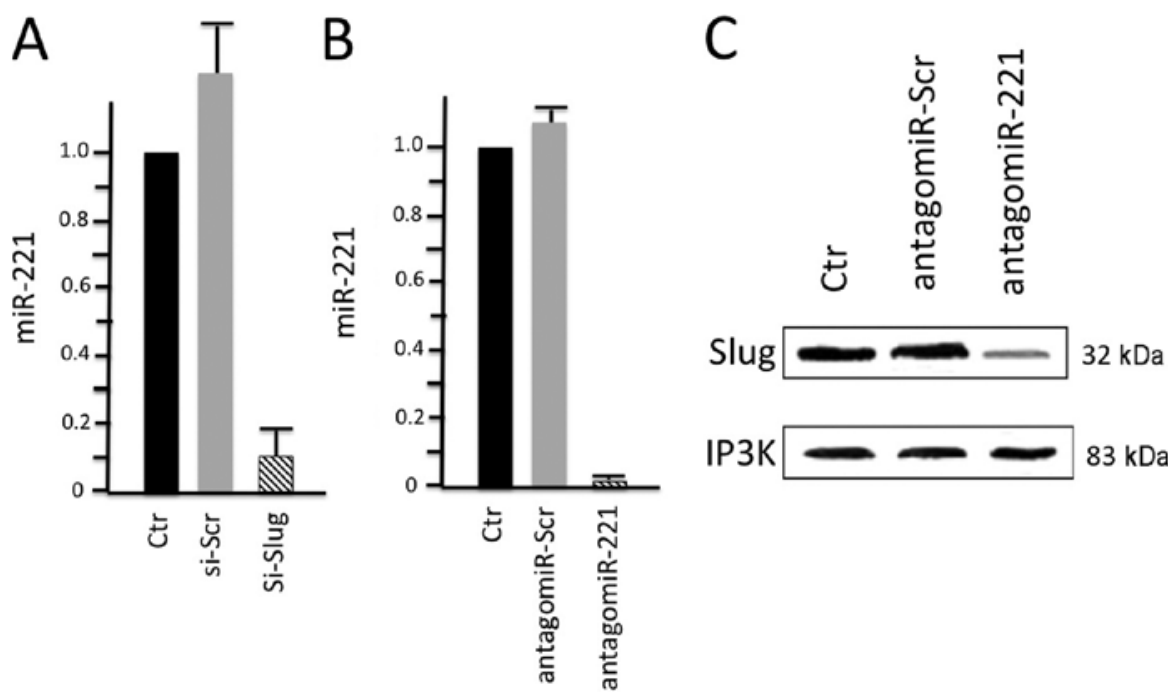

Figure 3. Effects of Slug silencing and antagomiR-221 treatment in MDA-MB-231 breast cancer cells. (A) Slug silencing, but not scrambled siRNA, markedly decreased miR-221 expression as demonstrated by qRT-PCR. (B and C) Treatment with antagomiR-221 abolished miR-221 expression and decreased Slug protein levels as shown by (B) qRT-PCR and (C) western blot analysis, respectively. IP3K was used as the loading control. Modified from the study by Lambertini $e t$ al (74). 
that miR-221 is a Slug target gene, and the authors identified a specific region of the miR-221 promoter that is transcriptionally active and binds the transcription factor Slug in vivo. In addition, they observed a more potent inhibiton of cell migration in the Slug-silenced cells, which retained residual miR-221 (approximately 38\%), compared with antagomiR-221-treated cells with a complete knockdown of miR-221. As a whole, their study reported for the first time evidence of a correlation between the Slug transcription factor and miR-221 in breast cancer cells, suggesting that miR-221 expression is, at least in part, dependent on Slug, which is more effective than miR-221 in sustaining cell migration and invasion.

\section{Effects of antagomiRs targeting oncomiRs}

In miRNA therapeutics, by targeting oncomiRs and metastamiRs, several strategies have been performed to inhibit the functions of oncomiRs and metastamiRs. One of the most common approaches involves the use of antisense miRNAs (antagomiRs) capable of knocking down miRNAs. Velu et al (76) demonstrated the efficacy of the knockdown of miR-21, which is involved in myelopoiesis, using antagomiRs in primary murine bone marrow stem/progenitor cells. This approach has a clear potential impact in anticancer therapy, as demonstrated in a very recent study by Poltronieri et al (77), who hypothesized that, as oncomiRs promote the growth of cancer cells and support survival during chemotherapy, thus miRNA-silencing therapies may be a valuable approach in conjunction with anticancer drugs and chemotherapy treatments. Specifically, they focused on miR-155, which they found overexpressed in different types of cancer. Of particular interest was the finding that GABA-A receptor downregulation was found to correlate with the glioma grade, with decreasing levels being associated with a higher grade of malignancy. The demonstration that the knockdown of miR-155 involves the re-expression of GABRA 1 protein in vivo has a great implication on the effectiveness of RNA-silencing approaches against miR-155, with the aim to control proliferation and signalling pathways regulated by the GABA-A receptor.

Another study also focused on potential anticancer therapy based on miRNA knockdown. Ma et al aimed to control mammary tumor metastasis (78). They demonstrated that the systemic treatment of tumor-bearing mice with miR-10b antagomiRs suppresses breast cancer metastasis, both in vitro and in vivo. The silencing of miR-10b with antagomiRs significantly decreased miR-10b levels and increased the levels of a functionally important miR-10b target, Hoxd10. Of note, the administration of miR-10b antagomiRs to mice bearing highly metastatic cells did not reduce primary mammary tumor growth but markedly suppressed the formation of lung metastases in a sequence-specific manner. The miR-10b antagomiR, which is well tolerated by healthy animals, appears to be a promising candidate for the development of novel anti-metastatic agents.

\section{Novel drugs in miRNA therapeutics: peptide nucleic acid (PNA)}

Peptide nucleic acid (PNA) (Fig. 4) is a DNA analogue in which the sugar-phosphate backbone is replaced by $\mathrm{N}$-(2-aminoethyl)
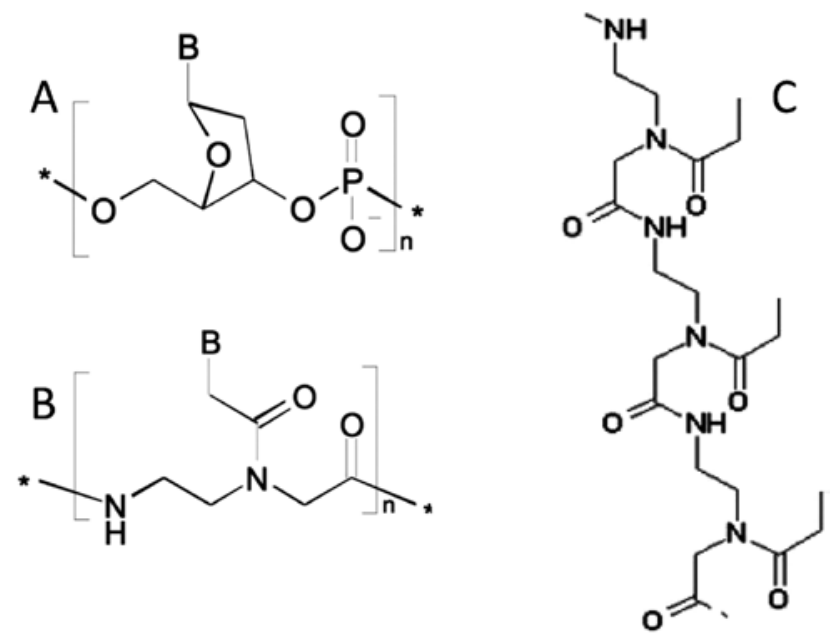

Figure 4. (A) DNA and (B) peptide nucleic acid (PNA) monomers. (C) PNA structure.

glycine units (79-84). These molecules efficiently hybridize with complementary DNA and RNA, forming a double helix with Watson-Crick base pairs $(79,80)$. Accordingly, PNA has been suggested for use in antisense and anti-gene therapy in a number of studies (83-86). PNA is promising for RNA recognition, since it has a higher affinity for RNA than for DNA, is more specific, and is resistant to DNases and proteases (80). PNA can be modified in order to achieve a better performance in terms of cellular permeation, higher affinity and specificity for the target DNA and RNA sequences (87-93).

In the case of the development of PNA-based miRNA therapeutics for altering gene expression in breast cancer cells, PNA targeting miR-221 has shown to specifically interact with miR-221 expressed in aggressive breast cancer cell lines (94). In order to maximize uptake in target cells, a polyarginine-peptide (R8) was conjugated, generating an anti-miR-221 PNA (R8-PNA-a221) displaying very high affinity for RNA and efficient uptake within target cells without the need of transfection reagents. Unmodified PNA with the same sequence displayed RNA binding, but cellular uptake was very poor. Consistently, only R8-PNA-a221 markedly inhibited miR-221 in MDA-MB-231 breast cancer cells. This is illustrated in Fig. 5A, describing the effects of two PNA-based antagomiRs, R8-PNA-a210 and R8-PNAa221, targeting miR-210 and miR-221, respectively. As it is clearly evident, R8-PNA-a210 inhibits miR-210 but not miR-221 and vice-versa, R8-PNAa221 inhibits miR-221 but not miR-210. Therefore, targeting miR-221 with R8-PNAa221 resulted in i) a specific decrease in the hybridization levels of miR-221 measured by qRT-PCR; and ii) the upregulation of $\mathrm{p} 27^{\text {Kip1 }}$, mRNA and protein, measured by qRT-PCR and western blot analysis (Fig. 5B and C).

While research on anti-miR PNA has just begun (95-100), pre-clinical results are expected in the near future to sustain the hypothesis that miRNA-targeted molecules based on PNA can be successfully applied to treat human diseases. An example was recently reported by Yan et al (101), who addressed the potential effects of PNA-anti-miR-21 in vivo on the growth of breast cancer cells. In their experiments, MCF-7 
A

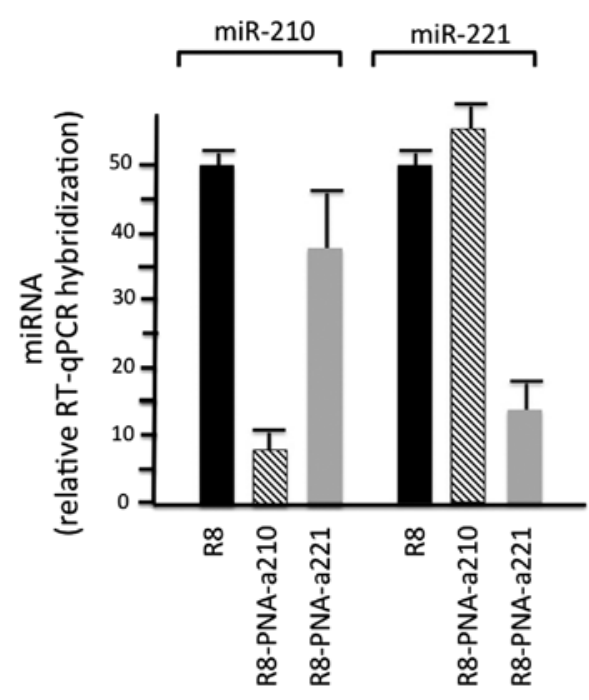

B

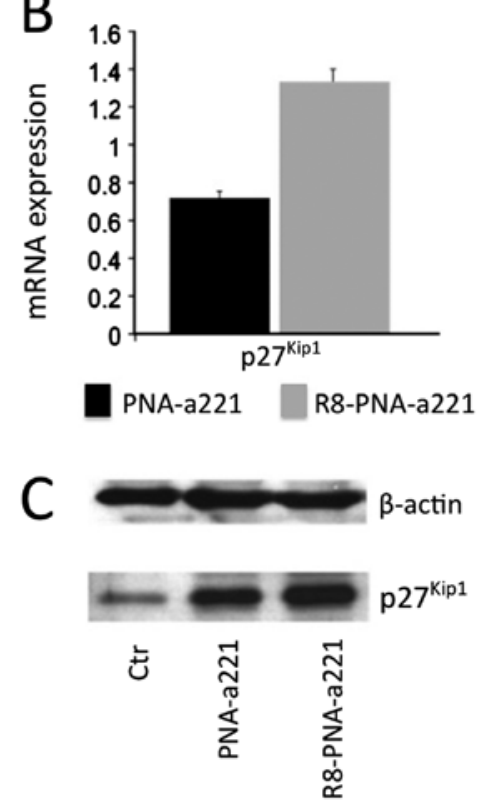

Figure 5. Effects of peptide nucleic acid (PNA)-based antagomiR against miR-221 in MDA-MB-231 breast cancer cells. (A) Effects of treatment of MDA-MB-231 cells (48 h) with $2 \mu$ M PNA-a221, PNA-a210, R8-PNA-a221 and R8-PNA-a210 on hybridization to probes recognizing miR-210 and miR-221, as indicated. (B and C) Accumulation of p27 ${ }^{\mathrm{Kip} 1}$ mRNA (B) in MDA-MB-231 cells treated for $96 \mathrm{~h}$ with $2 \mu \mathrm{M}$ PNA-a221 and Rpep-PNA-a221. (C) Western blot analysis performed on the same cellular population using antibody against $\mathrm{p} 27^{\mathrm{Kipl}}$ and against $\beta$-actin as reference protein. Modified from the study by Brognara et al (94).

cells treated with PNA-anti-miR-21 or PNA-control were subcutaneously injected into female nude mice. Detectable tumor masses were observed in only $5 / 8$ of mice in the $\mathrm{MCF} /$ PNA-anti-miR-21 group, while much larger tumors were detected in all mice in the MCF/PNA-control group. Both the tumor weight and number showed that MCF/PNA-control cells formed larger tumors more rapidly than the $\mathrm{MCF} /$ PNA-anti-miR-21 cells in nude mice.

\section{Conclusion}

The large number of studies on miRNAs in different types of in vitro and in vivo experimental models, both in basic and applied research, demonstrate the high prognostic, diagnostic and therapeutic value of these recently discovered molecules. The demonstration of the functions of these molecules has not only led to the discovery of a new system of regulation of gene expression that renews the concepts of molecular biology known to date, but has also allowed the development of novel clinical tools. The close collaboration between researchers and clinicians will be required in the near future to enhance the knowledge on the biology of miRNAs and exploit their potential to improve human health. In this context, miR-221 plays a crucial role in breast cancer for the following reasons: i) miR-221 is significantly overexpressed in triple-negative primary breast cancers; ii) the oncosuppressor $\mathrm{p} 27^{\mathrm{Kip} 1}$, a validated target of miR-221, is downregulated in aggressive cancer cell lines; and iii) the upregulation of a key transcription factor, Slug, appears to be crucial, since it binds to the $\mathrm{miR}-221 / \mathrm{miR}-222$ promoter and is responsible for the high expression of the miR-221/miR-222 cluster in breast cancer cells. A Slug/miR-221 network is thus proposed, linking miR-221 activity with the downregulation of a Slug repressor,
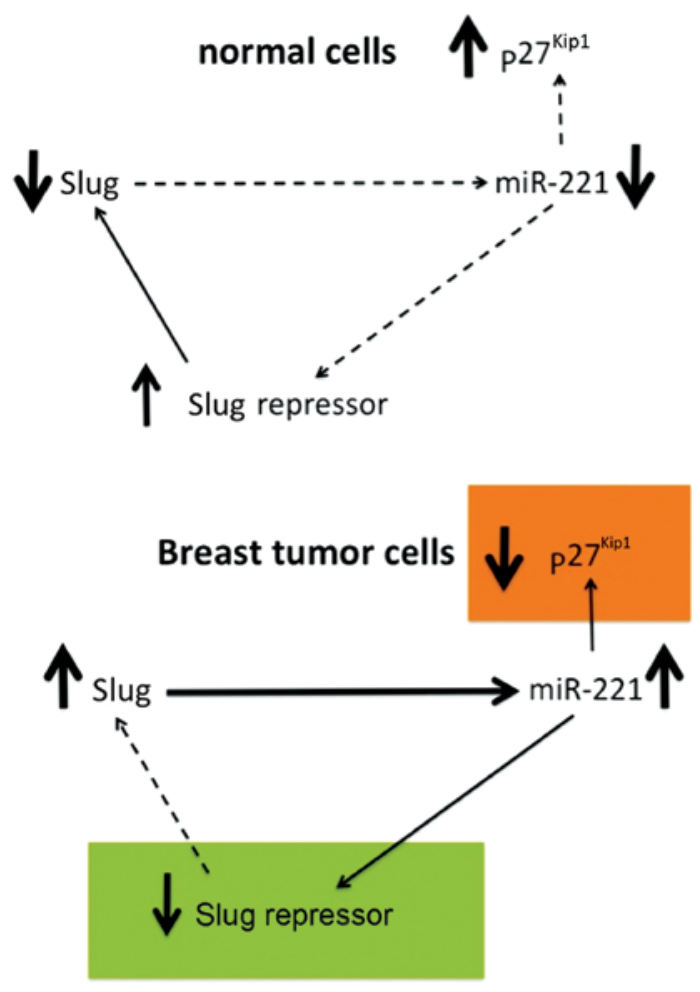

Figure 6. Schematic diagram outlining the interactions between miR-221, Slug and $\mathrm{p} 27^{\mathrm{Kip} 1}$ in breast cancer.

leading to Slug/miR-221 upregulation and p27 ${ }^{\mathrm{Kip} 1}$ downregulation (Fig. 6). Interference with this process can be achieved using antagomiR molecules targeting miR-221, inducing the downregulation of Slug and the upregulation of $\mathrm{p} 27^{\mathrm{Kip} 1}$. 
Targeting miR-221 with DNA analogues may be clinically relevant in antagomiR therapeutics.

\section{Acknowledgements}

This study was supported by a grant from MIUR (Italian Ministry of University and Research). R.G. received a grant from AIRC, Fondazione Cariparo (Cassa di Risparmio di Padova e Rovigo), CIB (Consorzio Interuniversitario di Biotecnologie).

\section{References}

1. Filipowicz W, Jaskiewicz L, Kolb FA and Pillai RS: Post-transcriptional gene silencing by siRNAs and miRNAs. Curr Opin Struc Biol 15: 331-341, 2005.

2. He L and Hannon GJ: MicroRNAs: small RNAs with a big role in gene regulation. Nat Rev Genet 5: 522-531, 2004.

3. Kozomara A and Griffiths-Jones S: miRBase: integrating microRNA annotation and deep-sequencing data. Nucleic Acids Res 39: D152-D157, 2011

4. Krol J, Loedige I and Filipowicz W: The widespread regulation of microRNA biogenesis, function and decay. Nat Rev Genet 11: 597-610, 2010.

5. Sontheimer EJ and Carthew RW: Silence from within: endogenous siRNAs and miRNAs. Cell 122: 9-12, 2005.

6. Taccioli C, Fabbri E, Visone R, Volinia S, Calin GA, Fong LY, et al: UCbase and miRfunc: a database of ultraconserved sequences and microRNA function. Nucleic Acids Res 37: D41-D48, 2009.

7. Griffiths-Jones S: miRBase: the microRNA sequence database. Methods Mol Biol 342: 129-138, 2006.

8. Witwer KW: Data submission and quality in microarray-based microRNA profiling. Clin Chem 59: 392-400, 2013.

9. Sablok G, Milev I, Minkov G, Minkov I, Varotto C, Yahubyan G, and Baev V: isomiRex: Web-based identification of microRNAs, isomiR variations and differential expression using nextgeneration sequencing datasets. FEBS Lett: Jul 4, 2013 (Epub ahead of print).

10. Russo F, Di Bella S, Nigita G, Macca V, Laganà A, Giugno R, Pulvirenti A and Ferro A: miRandola: extracellular circulating microRNAs database. PLoS One 7: e47786, 2012.

11. Krützfeldt J, Kuwajima S, Braich R, Rajeev KG, Pena J, Tuschl T, Manoharan M and Stoffel M: Specificity, duplex degradation and subcellular localization of antagomirs. Nucleic Acids Res 35: 2885-2892, 2007.

12. Dalmay T: Mechanism of miRNA-mediated repression of mRNA translation. Essays Biochem 54: 29-38, 2013.

13. Jiang Q, Wang Y, Hao Y, Juan L, Teng M, Zhang X, Li M, Wang G and Liu Y: miR2Disease: a manually curated database for microRNA deregulation in human disease. Nucleic Acids Res 37: D98-D104, 2009.

14. Subramanian S and Steer CJ: MicroRNAs as gatekeepers of apoptosis. J Cell Physiology 223: 89-98, 2010.

15. Wang YM and Blelloch R: Cell cycle regulation by MicroRNAs in embryonic stem cells. Cancer Res 69: 4093-4096, 2010.

16. Alvarez-Garcia I and Miska EA: MicroRNA functions in animal development and human disease. Development 132: 4653-4662, 2005.

17. Tsai LM and Yu D: MicroRNAs in common diseases and potential therapeutic applications. Clin Exp Pharmacol Physiol 7: 102-107, 2010

18. Hemida MG, Ye X, Thair S and Yang D: Exploiting the therapeutic potential of microRNAs in viral diseases: expectations and limitations. Mol Diagn Ther 14: 271-282, 2010.

19. Kota SK and Balasubramanian S: Cancer therapy via modulation of micro RNA levels: a promising future. Drug Discov Today 15 733-740, 2010.

20. Bader AG, Brown D and Winkler M: The promise of microRNA replacement therapy. Cancer Res 70: 7027-7030, 2010.

21. Sibley CR, Seow Y and Wood MJ: Novel RNA-based strategies for therapeutic gene silencing. Mol Ther 18: 466-476, 2010.

22. Ge YF, Sun J, Jin CJ, Cao BQ, Jiang ZF and Shao JF: AntagomiR-27a targets FOXO3a in glioblastoma and suppresses U87 cell growth in vitro and in vivo. Asian Pac J Cancer Prev 14: 963-968, 2013.
23. Rather MI, Nagashri MN, Swamy SS, Gopinath KS and Kumar A: Oncogenic microRNA-down-regulates tumor suppressor CDC73 and promotes oral squamous cell carcinoma cell proliferation: implications for cancer therapeutics. J Biol Chem 288: 608-618, 2013.

24. Shu M, Zheng X, Wu S, Lu H, Leng T, Zhu W, Zhou Y, Ou Y, Lin X, Lin Y, Xu D, Zhou Y and Yan G: Targeting oncogenic miR-335 inhibits growth and invasion of malignant astrocytoma cells. Mol Cancer 10: 59, 2011

25. Haug BH, Henriksen JR, Buechner J, Geerts D, Tømte E, Kogner P, Martinsson T, Flægstad T, Sveinbjørnsson B and Einvik C: MYCN-regulated miRNA-92 inhibits secretion of the tumor suppressor DICKKOPF-3 (DKK3) in neuroblastoma. Carcinogenesis 32: 1005-1012, 2011.

26. Tang H, Liu X, Wang Z, She X, Zeng X, Deng M, Liao Q, Guo X, Wang R, Li X, Zeng F, Wu M and Li G: Interaction of hsa-miR-381 and glioma suppressor LRRC4 is involved in glioma growth. Brain Res 1390: 21-32, 2011.

27. Ma L, Reinhardt F, Pan E, Soutschek J, Bhat B, Marcusson EG, Teruya-Feldstein J, Bell GW and Weinberg RA: Therapeutic silencing of miR-10b inhibits metastasis in a mouse mammary tumor model. Nat Biotechnol 28: 341-347, 2010.

28. Mercatelli N, Coppola V, Bonci D, Miele F, Costantini A, Guadagnoli M, Bonanno E, Muto G, Frajese GV, De Maria R, Spagnoli LG, Farace MG and Ciafrè SA: The inhibition of the highly expressed miR-221 and miR-222 impairs the growth of prostate carcinoma xenografts in mice. PLoS One 3: e4029, 2008.

29. Scheibner KA, Teaboldt B, Hauer MC, Chen X, Cherukuri S, Guo Y, Kelley SM, Liu Z, Baer MR, Heimfeld S and Civin CI: MiR-27a functions as a tumor suppressor in acute leukemia by regulating 14-3-30. PLoS One 7: e50895, 2012.

30. Endo H, Muramatsu T, Furuta M, Uzawa N, Pimkhaokham A, Amagasa T, Inazawa $\mathbf{J}$ and Kozaki K: Potential of tumorsuppressive miR-596 targeting LGALS3BP as a therapeutic agent in oral cancer. Carcinogenesis 34: 560-569, 2013.

31. Liang Z, Ahn J, Guo D, Votaw JR and Shim H: MicroRNA-302 replacement therapy sensitizes breast cancer cells to ionizing radiation. Pharm Res 30: 1008-1016, 2013.

32. Thomas M, Lange-Grünweller K, Weirauch U, Gutsch D, Aigner A, Grünweller A and Hartmann RK: The proto-oncogene Pim-1 is a target of miR-33a. Oncogene 31: 918-928, 2012.

33. Ibrahim AF, Weirauch U, Thomas M, Grünweller A, Hartmann RK and Aigner A: MicroRNA replacement therapy for miR-145 and miR-33a is efficacious in a model of colon carcinoma. Cancer Res 71: 5214-5224, 2011.

34. Wiggins JF, Ruffino L, Kelnar K, Omotola M, Patrawala L, Brown D and Bader AG: Development of a lung cancer therapeutic based on the tumor suppressor microRNA-34. Cancer Res 70: 5923-5930, 2010.

35. Trang P, Wiggins JF, Daige CL, Cho C, Omotola M, Brown D, Weidhaas JB, Bader AG and Slack FJ: Systemic delivery of tumor suppressor microRNA mimics using a neutral lipid emulsion inhibits lung tumors in mice. Mol Ther 19: 1116-1122, 2011.

36. Wu Y, Crawford M, Mao Y, Lee RJ, Davis IC, Elton TS, Lee LJ and Nana-Sinkam SP: Therapeutic delivery of microRNA-29b by cationic lipoplexes for lung cancer. Mol Ther Nucleic Acids 2: e84, 2013.

37. Huang $X$, Schwind S, Yu B, Santhanam R, Wang $H$, Hoellerbauer P, Mims A, Klisovic R, Walker AR, Chan KK, Blum W, Perrotti D, Byrd JC, Bloomfield CD, Caligiuri MA, Lee RJ, Garzon R, Muthusamy N, Lee LJ and Marcucci G: Targeted delivery of microRNA-29b by transferrin-conjugated anionic lipopolyplex nanoparticles: a novel therapeutic strategy in acute myeloid leukemia. Clin Cancer Res 19: 2355-2367, 2013.

38. Voorhoeve PM, le Sage C, Schrier M, Gillis AJ, Stoop H, Nagel R, Liu YP, van Duijse J, Drost J, Griekspoor A, Zlotorynski E, Yabuta N, De Vita G, Nojima H, Looijenga LH and Agami R: A genetic screen implicates miRNA-372 and miRNA-373 as oncogenes in testicular germ cell tumors. Cell 124: 1169-1181, 2006.

39. Voorhoeve PM, le Sage C, Schrier M, Gillis AJ, Stoop H, Nagel R, Liu YP, van Duijse J, Drost J, Griekspoor A, Zlotorynski E, Yabuta N, De Vita G, Nojima H, Looijenga LH and Agami R: A genetic screen implicates miRNA-372 and miRNA-373 as oncogenes in testicular germ cell tumors. Adv Exp Med Biol 604: 17-46, 2007.

40. Huang Q, Gumireddy K, Schrier M, le Sage C, Nagel R, Nair S, Egan DA, Li A, Huang G, Klein-Szanto AJ, Gimotty PA, Katsaros D, Coukos G, Zhang L, Puré E and Agami R: The microRNAs miR-373 and miR-520c promote tumour invasion and metastasis. Nat Cell Biol 10: 202-210, 2008. 
41. Galardi S, Mercatelli N, Giorda E, Massalini S, Frajese GV, Ciafrè SA and Farace MG: miR-221 and miR-222 expression affects the proliferation potential of human prostate carcinoma cell lines by targeting p27 ${ }^{\mathrm{Kipl}}$. J Biol Chem 282: 23716-23724, 2007.

42. Valastyan S, Reinhardt F, Benaich N, Calogrias D, Szász AM Wang ZC, Brock JE, Richardson AL and Weinberg RA: A pleiotropically acting microRNA, miR-31, inhibits breast cancer metastasis. Cell 137: 1032-1046, 2009.

43. Hurst DR, Edmonds MD and Welch DR: Metastamir: the field of metastasis-regulatory microRNA is spreading. Cancer Res 69 : 7495-7498, 2009.

44. Wotschofsky Z, Liep J, Meyer HA, Jung M, Wagner I, Disch AC, Schaser KD, Melcher I, Kilic E, Busch J, Weikert S, Miller K, Erbersdobler A, Mollenkopf HJ and Jung K: Identification of metastamirs as metastasis-associated microRNAs in clear cell renal cell carcinomas. Int J Biol Sci 8: 1363-1374, 2012.

45. Taylor MA, Sossey-Alaoui K, Thompson CL, Danielpour D and Schiemann WP: TGF- $\beta$ upregulates miR-181a expression to promote breast cancer metastasis. J Clin Invest 123: 150-163, 2013.

46. Welch DR and Hurst DR: Unraveling the 'TGF- $\beta$ paradox' one metastamir at a time. Breast Cancer Res 15: 305, 2013.

47. Moldovan L, Batte K, Wang Y, Wisler J and Piper M: Analyzing the circulating microRNAs in exosomes/extracellular vesicles from serum or plasma by qRT-PCR. Methods Mol Biol 1024: $129-145,2013$

48. Chen X, Liang H, Zhang J, Zen K and Zhang CY: Horizontal transfer of microRNAs: molecular mechanisms and clinical applications. Protein Cell 3: 28-37, 2012.

49. Kosaka $\mathrm{N}$ and Ochiya T: Unraveling the mystery of cancer by secretory microRNA: horizontal microRNA transfer between living cells. Front Genet 2: 97, 2011.

50. Chen X, Liang H, Zhang J, Zen K and Zhang CY: Secreted microRNAs: a new form of intercellular communication. Trends Cell Biol 22: 125-132, 2012.

51. Ramachandran S and Palanisamy V: Horizontal transfer of RNAs: exosomes as mediators of intercellular communication. Wiley Interdiscip Rev RNA 3: 286-293, 2012.

52. Muralidharan-Chari V, Clancy JW, Sedgwick A and D'Souza-Schorey C: Microvesicles: mediators of extracellular communication during cancer progression. J Cell Scil 23: $1603-1611,2010$

53. Piovan C,Palmieri D, Di Leva G, Braccioli L, Casalini P, Nuovo G, Tortoreto M, Sasso M, Plantamura I, Triulzi T, Taccioli C, Tagliabue E, Iorio MV and Croce CM: Oncosuppressive role of p53-induced miR-205 in triple negative breast cancer. Mol Oncol 6: 458-472, 2012

54. Lee YM, Lee JY, Ho CC, Hong QS, Yu SL, Tzeng CR, Yang PC and Chen HW: miRNA-34b as a tumor suppressor in estrogendependent growth of breast cancer cells. Breast Cancer Res 13 R116, 2011.

55. Iorio MV and Croce CM: Causes and consequences of microRNA dysregulation. Cancer J 18: 215-222, 2012.

56. Xu X, Chen H, Lin Y, Hu Z, Mao Y, Wu J, Xu X, Zhu Y, Li S, Zheng $X$ and Xie L: MicroRNA-409-3p inhibits migration and invasion of bladder cancer cells via targeting c-Met. Mol Cells 36: 62-68, 2013.

57. He J, Deng Y, Yang G and Xie W: MicroRNA-203 down-regulation is associated with unfavorable prognosis in human glioma. J Surg Oncol 108: 121-125, 2013.

58. Iorio MV and Croce CM: MicroRNAs in cancer: small molecules with a huge impact. J Clin Oncol 27: 5848-5856, 2009.

59. Volinia S, Galasso M, Sana ME, Wise TF, Palatini J, Huebner K and Croce CM: Breast cancer signatures for invasiveness and prognosis defined by deep sequencing of microRNA. Proc Natl Acad Sci USA 109: 3024-3029, 2012.

60. Lu Y, Roy S, Nuovo G, Ramaswamy B, Miller T, Shapiro C, Jacob ST and Majumder S: Anti-microRNA-222 (anti-miR-222) and -181B suppress growth of tamoxifen-resistant xenografts in mouse by targeting TIMP3 protein and modulating mitogenic signal. J Biol Chem 286: 42292-42302, 2011.

61. Shah MY and Calin GA: MicroRNAs miR-221 and miR-222: a new level of regulation in aggressive breast cancer. Genome Med 3: 56, 2011.

62. Stinson S, Lackner MR, Adai AT, Yu N, Kim HJ, O'Brien C, Spoerke J, Jhunjhunwala S, Boyd Z, Januario T, Newman RJ, Yue P, Bourgon R, Modrusan Z, Stern HM, Warming S, de Sauvage FJ, Amler L, Yeh RF and Dornan D: miR-221/222 targeting of trichorhinophalangeal 1 (TRPS1) promotes epithelial-to-mesenchymal transition in breast cancer. Sci Signal 4: pt5, 2011.
63. Cochrane DR, Cittelly DM, Howe EN, Spoelstra NS, McKinsey EL, LaPara K, Elias A, Yee D and Richer JK: MicroRNAs link estrogen receptor alpha status and Dicer levels in breast cancer. Horm Cancer 1: 306-319, 2010.

64. Yoshimoto N, Toyama T, Takahashi S, Sugiura H, Endo Y, Iwasa M, Fujii Y and Yamashita H: Distinct expressions of microRNAs that directly target estrogen receptor $\alpha$ in human breast cancer. Breast Cancer Res Treat 130: 331-339, 2011.

65. Stinson S, Lackner MR, Adai AT, Yu N, Kim HJ, O'Brien C, Spoerke J, Jhunjhunwala S, Boyd Z, Januario T, Newman RJ, Yue P, Bourgon R, Modrusan Z, Stern HM, Warming S, de Sauvage FJ, Amler L, Yeh RF and Dornan D: TRPS1 targeting by miR-221/222 promotes the epithelial-to-mesenchymal transition in breast cancer. Sci Signal 4: ra41, 2011.

66. Guttilla IK, Phoenix KN, Hong X, Tirnauer JS, Claffey KP and White BA: Prolonged mammosphere culture of MCF-7 cells induces an EMT and repression of the estrogen receptor by microRNAs. Breast Cancer Res Treat 132: 75-85, 2012.

67. Gordanpour A, Stanimirovic A, Nam RK, Moreno CS, Sherman C, Sugar L and Seth A: miR-221 is down-regulated in TMPRSS2: ERG fusion-positive prostate cancer. Anticancer Res 31: 403-410, 2011.

68. Radojicic J, Zaravinos A, Vrekoussis T, Kafousi M, Spandidos DA and Stathopoulos EN: MicroRNA expression analysis in triple-negative (ER, PR and Her2/neu) breast cancer. Cell Cycle 10: 507-517, 2011.

69. Pelletier C, Speed WC, Paranjape T, Keane K, Blitzblau R, Hollestelle A, Safavi K, van den Ouweland A, Zelterman D, Slack FJ, Kidd KK and Weidhaas JB: Rare BRCA1 haplotypes including 3'UTR SNPs associated with breast cancer risk. Cell Cycle 10: 90-99, 2011.

70. Rao X, Di Leva G, Li M, Fang F, Devlin C, Hartman-Frey C, Burow ME, Ivan M, Croce CM and Nephew KP: MicroRNA221/222 confers breast cancer fulvestrant resistance by regulating multiple signaling pathways. Oncogene 30: 1082-1097, 2011.

71. Zhou M, Liu Z, Zhao Y, Ding Y, Liu H, Xi Y, Xiong W, Li G, Lu J, Fodstad O, Riker AI and Tan M: MicroRNA-125b confers the resistance of breast cancer cells to paclitaxel through suppression of pro-apoptotic Bcl-2 antagonist killer 1 (Bak1) expression. J Biol Chem 285: 21496-21507, 2010.

72. Di Leva G, Gasparini P, Piovan C, Ngankeu A, Garofalo M, Taccioli C, Iorio MV, Li M, Volinia S, Alder H, Nakamura T, Nuovo G, Liu Y, Nephew KP and Croce CM: MicroRNA cluster 221-222 and estrogen receptor alpha interactions in breast cancer. J Natl Cancer Inst 102: 706-721, 2010.

73. Pogribny IP, Filkowski JN, Tryndyak VP, Golubov A, Shpyleva SI and Kovalchuk O: Alterations of microRNAs and their targets are associated with acquired resistance of MCF-7 breast cancer cells to cisplatin. Int J Cancer 127: 1785-1794, 2010.

74. Lambertini E, Lolli A, Vezzali F, Penolazzi L, Gambari R and Piva R: Correlation between Slug transcription factor and miR-221 in MDA-MB-231 breast cancer cells. BMC Cancer 12: $445,2012$.

75. Zhao R, Wu J, Jia W, Gong C, Yu F, Ren Z, Chen K, He J and Su F: Plasma miR-221 as a predictive biomarker for chemoresistance in breast cancer patients who previously received neoadjuvant chemotherapy. Onkologie 34: 675-680, 2011.

76. Velu CS and Grimes HL: Utilizing antagomiR (antisense microRNA) to knock down microRNA in murine bone marrow cells. Methods Mol Biol 928: 185-195, 2012.

77. Poltronieri P, D'Urso PI, Mezzolla V and D'Urso OF: Potential of anti-cancer therapy based on anti-miR-155 oligonucleotides in glioma and brain tumours. Chem Biol Drug Des 81: 79-84, 2013.

78. Ma D, Tao X, Gao F, Fan C and Wu D: miR-224 functions as an onco-miRNA in hepatocellular carcinoma cells by activating AKT signaling. Oncol Lett 4: 483-488, 2012.

79. Nielsen PE, Egholm M, Berg RH and Buchardt $\mathrm{O}$ : Sequence-selective recognition of DNA by strand displacement with a thymine-substituted polyamide. Science 254 : 1497-1500, 1991.

80. Demidov VV and Frank-Kamenetskii MD: Sequence-specific targeting of duplex DNA by peptide nucleic acids via triplex strand invasion. Methods 23: 108-122, 2001

81. Gambari R: Peptide-nucleic acids (PNAs): a tool for the development of gene expression modifiers. Curr Pharm Des 7: 1839-1862, 2001.

82. Karkare S and Bhatnagar D: Promising nucleic acid analogs and mimics: characteristic features and applications of PNA, LNA, and morpholino. Appl Microbiol Biotechnol 71: 575-586, 2006. 
83. Nielsen PE: Antisense peptide nucleic acids. Curr Opin Mol Ther 2: 282-287, 2002.

84. Soomets U, Hällbrink M and Langel U: Antisense properties of peptide nucleic acids. Front Biosci 4: D782-D786, 1999.

85. Ray A and Nordén B: Peptide nucleic acid (PNA): its medical and biotechnical applications and promise for the future. FASEB J 14: 1041-1060, 2000.

86. Nielsen PE: Targeting double stranded DNA with peptide nucleic acid (PNA). Curr Med Chem 8: 545-550, 2001

87. Gambari R: Biological activity and delivery of peptide nucleic acids (PNA)-DNA chimeras for transcription factor decoy (TFD) pharmacotherapy. Curr Med Chem 11: 1253-1263, 2004.

88. Corradini R, Sforza S, Tedeschi, T, Totsingan F and Marchelli R: Peptide nucleic acids with a structurally biased backbone: effects of conformational constraints and stereochemistry. Curr Top Med Chem 7: 681-694, 2007.

89. Sforza S, Tedeschi T, Calabretta A, Corradini R, Camerin C, Tonelli R, Pession A and Marchelli R: A peptide nucleic acid embedding a pseudopeptide nuclear localization sequence in the backbone behaves as a peptide mimic. Eur J Org Chem 13: 2441-2444, 2010.

90. Sforza S, Corradini R, Ghirardi S, Dossena A and Marchelli R: DNA binding of a D-Lysine-based chiral PNA: direction control and mismatch recognition. Eur J Org Chem 16: 2905-2913, 2000.

91. Sforza S, Tedeschi T, Corradini R and Marchelli R: Induction of helical handedness and DNA binding properties of peptide nucleic acids (PNAs) with two stereogenic centres. Eur J Org Chem 35: 5879-5885, 2007.

92. Tedeschi T, Sforza S, Corradini R and Marchelli R: Synthesis of new chiral PNAs bearing a dipeptide-mimic monomer with two lysine-derived stereogenic centres. Tetrahedron Lett 46: 8395-8399, 2005.

93. Dragulescu-Andrasi A, Zhou P, He G and Ly DH: Cell-permeable GPNA with appropriate backbone stereochemistry and spacing binds sequence-specifically to RNA. Chem Commun 3: 244-246, 2005.
94. Brognara E, Fabbri E, Aimi F, Manicardi A, Bianchi N, Finotti A Breveglieri G, Borgatti M, Corradini R, Marchelli R and Gambari R: Peptide nucleic acids targeting miR-221 modulate p2 $7^{\text {Kipl }}$ expression in breast cancer MDA-MB-231 cells. Int J Oncol 41: 2119-2127, 2012.

95. Gambari R, Fabbri E, Borgatti M, Lampronti I, Finotti A, Brognara E, Bianchi N, Manicardi A, Marchelli R and Corradini R: Targeting microRNAs involved in human diseases: a novel approach for modification of gene expression and drug development. Biochem Pharmacol 82: 1416-1429, 2011.

96. Fabani MM and Gait MJ: miR-122 targeting with LNA/2'-Omethyloligonucleotide mixmers, peptide nucleic acids (PNA), and PNA-peptide conjugates. RNA 14: 336-346, 2008.

97. Fabani MM, Abreu-Goodger C, Williams D, Lyons PA, Torres AG, Smith KGC, et al: Efficient inhibition of miR-155 function in vivo by peptide nucleic acids. Nucleic Acids Res 38: 4466-4475, 2010.

98. Fabbri E, Manicardi A, Tedeschi T, Sforza S, Bianchi N, Brognara E, Finotti A, Breveglieri G, Borgatti M, Corradini R, Marchelli R and Gambari R: Modulation of the biological activity of microRNA-210 with peptide nucleic acids (PNAs). Chem Med Chem 6: 2192-2202, 2011

99. Fabbri E, Brognara E, Borgatti M, Lampronti I, Finotti A, Bianchi N, Sforza S, Tedeschi T, Manicardi A, Marchelli R, Corradini R and Gambari R: miRNA therapeutics: delivery and biological activity of peptide nucleic acids targeting miRNAs. Epigenomics 3: 733-745, 2011.

100. Manicardi A, Fabbri E, Tedeschi T, Sforza S, Bianchi N, Brognara E, Gambari R, Marchelli R and Corradini R: Cellular uptakes, biostabilities and anti-miR-210 activities of chiral arginine-PNAs in leukaemic K562 cells. Chembiochem 13: 1327-1337.

101. Yan LX, Wu QN, Zhang Y, Li YY, Liao DZ, Hou JH, Fu J, Zeng MS, Yun JP, Wu QL, Zeng YX and Shao JY: Knockdown of miR-21 in human breast cancer cell lines inhibits proliferation, in vitro migration and in vivo tumor growth. Breast Cancer Res 13: R2, 2011. 